\title{
Whither NerVous SHOCK? THE Current State, Future Direction AND POSSIBLE REFORM OF COMPENSATION FOR NEGLIGENTLY INFLICTED PSYCHIATRIC INJURY AFTER RAMSTEAD
}

\author{
Peter Richmond McRae
}

Whether compensation should be available for psychiatric injury, traditionally labelled "nervous shock", has been a vexed question whether considered by the courts or by regulatory bodies in terms of the Accident Compensation scheme. In this article, the author provides an analysis of the evolution of compensation for nervous shock in New Zealand, from its incorporation in the original Accident Compensation Act 1972, its release into tort by the 1992 Act and its subsequent development by the courts up until the Court of Appeal decision in Ramstead. The decision in Ramstead is then analysed, and its implications for the tort discussed in light of the United Kingdom and Australian jurisprudence. Ultimately, the author concludes that nervous shock is better dealt with under the statutory compensation scheme and canvasses the arguments made in support and against this proposition.

\section{INTRODUCTION}

It might be thought there is little left to be said on nervous shock. The matter has been controversial in New Zealand and overseas for at least a decade, many relevant cases of high

\footnotetext{
* This paper was submitted in fulfilment of the LLB(Hons) requirements at Victoria University in 2000.
} 
authority have been decided, and much academic and official commentary has been written. ${ }^{1}$ However, the law in New Zealand is in a state of development, due in part to its having been frozen under accident compensation and latterly released back into tort law in 1992. It has therefore been unclear to what extent or which of the overseas authorities and approaches apply here, as the matter has awaited relevant cases.

Consideration of compensation for "nervous shock", or negligently inflicted psychiatric injury in New Zealand is therefore timely for at least three reasons. First, the Court of Appeal has recently considered the matter in some detail, in $J \& P$ Van Soest \& Others $v$ Residual Health Management Unit and $K$ Ramstead. ${ }^{2}$ The judgment has clarified some matters, in particular the need for a recognisable psychiatric illness. ${ }^{3}$ Other important issues have been left undecided, including whether "secondary" victims must satisfy any special proximity requirements, and whether an actual "shocking incident", involving actual or threatened injury to some primary victim is required. ${ }^{4}$ Further, while the Court was unanimous as to the result, Thomas $\mathrm{J}$ has expressed sharply differing views, both on points decided and those left open by the "majority"..$^{5}$ The extent, rationale and requirements for liability for nervous shock in New Zealand remain unsettled, and will be further explored in this article, together with options to resolve current uncertainties.

Secondly and at a more basic level, it is timely to explore whether there should even be the facility for liability in negligence for nervous shock in New Zealand. Such liability only became a possibility after the Accident Rehabilitation, Compensation and Insurance Act 1992 removed

1 McLoughlin v O'Brien [1983] 1 AC 410 (HL); Alcock v Chief Constable of South Yorkshire [1992] 1 AC 310 (HL); McFarlane v EE Caledonia Ltd [1994] 2 All ER 1 (CA); Page v Smith[1996] 1 AC 155 (HL); White v Chief Constable of South Yorkshire [1999] 1 All ER 1 (HL); Jaensch v Coffey (1984) 155 CLR 549; Spence v Percy [1992] 2 Qd R 299 (CA); Coates v Government Insurance Office of NSW (1995) 36 NSWLR 1 (CA); Reeve v Brisbane City Council [1995] 2 Qd R 661 (CA); Pham v Lawson (1997) 68 SASR 124 (CA); for official comment see UK Law Commission Liability for Psychiatric Illness: (LAW COM 249, London, 1998) [Law Commission 1998]; for academic treatment see N J Mullany and P R Handford Tort Liability for Psychiatric Damage (The Law Book Company Ltd, Sydney, 1993); but see Christian Witting "A Primer on the Modern Law of 'Nervous Shock" [1998] 22 Melb U LR 62 for a contrasting approach.

$2 J \& P$ Van Soest \& Others $v$ Residual Health Management Unit and K Ramstead [2000] 1 NZLR 179 (CA) [Ramstead].

3 Ramstead, above n 2, para 65.

4 Ramstead, above n 2, paras 72-74.

$5 \quad$ Ramstead, above n 2, para 78 
purely mental injury from cover, ${ }^{6}$ and a reality after Queenstown Lakes District Council v Palmer. ${ }^{7}$ Accident compensation is again subject to fundamental review, and this should include whether psychiatric and physical injury should continue to be separated. ${ }^{8}$ This article argues that a simple, effective and principled option for resolving the role of nervous shock in tort law is to remove it, and once again allow accident compensation for pure mental injury.

Thirdly, whatever its place, nervous shock's importance cannot be ignored. Recent cases suggest plaintiffs or claimants are increasingly likely to seek compensation for purely psychiatric, or psychiatrically-founded injuries. ${ }^{9}$ While this is hardly surprising, in a society subject to decades of restructuring, and also to increasing awareness of the importance and prevalence of psychiatric illness, ${ }^{10}$ it does suggest the basis of such compensation, if any, should be explored. If compensation is likely to become common, we should understand why such injuries attract compensation in the first place, and identify compensation's proper role and limits. This will also help to determine whether tort or accident compensation is the better path.

The article examines the development of nervous shock, overseas and in New Zealand. It then examines Ramstead, to establish the current law in New Zealand, whether it makes sense, and what problems remain. It then explores options for the future. I conclude that while tort provision need not be arbitrary, accident compensation is more likely to achieve the aims of compensation, is likely to be efficient, and better avoids the need for arbitrary limitations on availability of compensation.

6 Accident Rehabilitation, Compensation and Insurance Act 1992, s 3

7 Queenstown Lakes District Council v Palmer [1999] 1 NZLR 549 (CA).

8 The authorities increasingly accept that any such distinction is artificial: Page v Smith, above n 1,188 per Lord Lloyd; Coates $v$ GIO, above n 1, 15 per Kirby P (dissenting). See also Mullany's impassioned argument re the artificiality of the distinction: Nicholas J Mullany "Fear for the future: liability for infliction of psychiatric disorder" in Mullany (ed) Torts in the Nineties (Law Book Company, Sydney, 1997) $101,101-107$.

9 See Brickell v Attorney General (9 June 2000) unreported, High Court, Wellington CP 267/97; Gilbert v Attorney General, (21 June 2000) unreported, Employment Court, Auckland AC 49/00. Although neither case was founded in tort, the links to nervous shock and potentially accident compensation are obvious.

10 See above $\mathrm{n}$ 8. Public health television advertising also commonly reports that such illness habitually affects 20 per cent of the population. 
Something should be said about terminology and coverage. The article will continue to use the term "nervous shock", to describe generically the category of liability that has grown up in negligence. It is least confusing to use the traditional label, while such injury is dealt with in tort. While the language is outdated and misleading ${ }^{11}$ it is preferred to "psychiatric injury", both for reasons of continuity, and because otherwise "psychiatric injury" would have to do dual service, as both category and a component requirement for liability. Despite its in adequacies, "nervous shock" can still serve as a convenient label for the potential tort liability. No doubt if it is reabsorbed by accident compensation, the label will quietly disappear, replaced by the relevant Act's definition of "mental injury".

The article concentrates on the so-called "secondary victims" of nervous shock. It does not enter the debate over the contested borders between primary and secondary victims, or whether the distinction is useful, ${ }^{12}$ nor does it examine the less restrictive requirements placed on primary victims. Ramstead is a secondary victims case, and it is with secondary victims, however defined, that the existing requirements are most problematic. The easier road to redress for primary victims does however point to why we regard psychiatric harm as compensable at all, and is discussed in that light below.

\section{HISTORY AND DEVELOPMENT OF NERVOUS SHOCK \\ A United Kingdom}

Liability for negligently inflicted nervous shock in at least some cases has been allowed for almost a hundred years. When first considered in the nineteenth century the possibility was disallowed, for fear of fraudulent claims and indeterminate liability. ${ }^{13}$ It is easy to speculate that the perceived high risk of fraud was largely due to relatively poor understanding and diagnosis of psychiatric illness. ${ }^{14}$ The position soon changed however, with Dulieu $v$ White, ${ }^{15}$ which allowed primary victims of shocking incidents to recover, so long as they were put in fear of injury to themselves, and suffered physical or mental harm as a result. Hambrook $v$ Stokes

11 Ramstead, above n 2, para 97, per Thomas J.

12 See for instance White $v$ Chief Constable, above n 1, 18-21 per Lord Goff.

13 Victorian Railways Commissioners v Coultas (1888) 13 App Cas 222 (PC). See Stephen Todd (ed) The Law of Torts in New Zealand (Brooker's, Wellingto n, 1997) 190.

14 Mullany, above n 8, 105, n 14.

15 Dulieu v White [1901] 2 KB 669, 675. 
Bros $^{16}$ established that fear or knowledge of injury to others, especially loved ones, could suffice, meaning that those referred to today as secondary victims could recover. As Lord Wilberforce noted in McLoughlin v $O^{\prime}$ Brien, ${ }^{17}$ Hambrook distinguished between actual sight and sound, and being told of injury by others, laying the foundations for later requirements for some sort of physical proximity. Thus while Hambrook suggested the potential for wider availability of a remedy, it also highlighted concern over such potential width and the need for appropriate limitations. This theme runs throughout later cases.

Bourhill $v$ Young ${ }^{18}$ considered proximity further and decided that mere hearing from a distance was insufficient. Also, potential plaintiffs should be assumed to have "reasonably normal" susceptibility to shock, or "ordinary phlegm", so that potential tortfeasors would not be liable for people with unforeseeably heightened sensitivity. ${ }^{19}$ The House therefore continued to allow potential liability, but was beginning the process of deciding what the appropriate "common sense" or policy limitations were needed.

This process continued in McLoughlin. While Lords Bridge and Scarman preferred to rely simply on whether injury was reasonably foreseeable, ${ }^{20}$ Lord Wilberforce recognised that limits of liability is a policy question, and discussed factors indicating restraint, including proliferation of claims, possible fraud, disproportionate economic costs, difficulties of evidence and the roles of courts or Parliament. He concluded the famous three part test of proximity of relationship, closeness in time and space, and the means by which the shock was communicated. The test amounted to an extension of the circumstances of liability, as it extended immediate aftermath to include attendance at a hospital a short time later, before victims had been cleaned up and were still distressed. ${ }^{21}$

Alcock $v$ Chief Constable of South Yorkshire is now the leading United Kingdom case. In the wake of the Hillsborough tragedy, a majority of the House of Lords confirmed the tripartite test, and refined the relationship arm to include those with close ties of love and affection. Such

16 Hambrook v Stokes Bros [1925] 1 KB 141, 151 (CA).

17 McLoughlin v O'Brien, above n 1, 418.

18 Hay or Bourhill v Young [1943] AC 92 (HL).

19 Bourhill, above n 18, 110, 117. But see Page v Smith, above n 1, 189 re need for ordinary phlegm for "primary" victims. See also n 29 below.

20 McLoughlin, above n 1, 441 per Lord Bridge; 430-431 per Lord Scarman.

21 McLoughlin, above n 1, 420-423. 
ties could still be presumed between parents, children and spouses, but must be proved by the plaintiff in other cases. ${ }^{22}$ The door was not completely closed on shocked bystanders witnessing a particularly horrific event, ${ }^{23}$ but this possibility was later discounted. ${ }^{24}$ Their Lordships also confirmed the need for psychiatric illness, ${ }^{25}$ and for a "shock" - "a sudden assault on the mind", ${ }^{26}$ or "the sudden appreciation by sight or sound of a horrifying event which violently agitates the min $\mathrm{d}^{2} .^{27}$

There was some appreciation by the majority that the tests were subject to criticism as arbitrary or illogical. Lord Oliver did not regard the current state of the law as either entirely satisfactory or logically defensible, but considered any expansion should be by Parliament. ${ }^{28}$ The current restrictions were apparently considered necessary to prevent a potential flood of liability, despite their lack of logic.

Page $v$ Smith, a primary victim case, nevertheless confirmed that secondary victims are expected to have "normal phlegm" or "reasonable fortitude". ${ }^{29}$ Therefore, as well as the tripartite test, plaintiffs must show psychiatric injury, suffered as the result of a "shock", that would be reasonably foreseeable to result to a person with reasonable fortitude in the position of the plaintiff. There are thus at least six hurdles for plaintiffs to clear, over and above the normal elements of negligence. Nervous shock, if not defined out of existence, is limited to very narrow and arbitrarily defined categories of persons and circumstances.

The unsatisfactory nature of this law has been recognised. The Law Commission published a consultation paper on the subject in 1995 and released its conclusions in $1998 .{ }^{30}$ The Commission concluded that the law after Alcock is unduly restrictive and leads to arbitrary results. They found overwhelming support for removal of the restrictions requiring temporal

22 Alcock, above n 1, 397-398.

23 Alcock, above n 1, 403 per Lord Ackner.

24 By the Court of Appeal: McFarlane v EE Caledonia, above n 1, 14.

25 Alcock, above n 1, 396 per Lord Keith, 399 per Lord Ackner, 415 per Lord Oliver.

26 Alcock, above n 1, 398 per Lord Keith.

27 Alcock, above n 1, 401 per Lord Ackner.

28 Alcock, above n 1, 417.

29 Page v Smith, above n 1, 155, 189.

30 Law Commission 1998, above n 1. 
and physical proximity to an accident, and for direct perception. ${ }^{31}$ They also recommen ded the requirement for injury by a "shock" be abandoned, as it leads to some of the harshest and most arbitrary of results. ${ }^{32}$ The Commission considered however that a simple requirement for foreseeability of psychiatric injury alone would be insufficient as a gatekeeper to liability, as there "would or could" be significant floodgates problems. ${ }^{33}$ This view was driven by concern over proliferation of claims from a single event, with liability therefore disproportionate to the original negligence, although the potential for an overall increase in the number of claims was also unacceptable. ${ }^{34}$ The Commission clearly felt that the perceived soft dividing line between levels of mental disturbance which will or will not amount to psychiatric illness, and the widening of the concept of mental illness required caution. ${ }^{35}$

The Commission's approach respect can therefore be seen as still essentially limiting, compared to the approach of, for instance, Mullany and Handford, and of course Thomas $J$ in Ramstead who follows them. ${ }^{36}$ They do not accept that liability should be limited merely because more people are potentially affected, and there is allegedly a risk of disproportionate liability: "every man that is injured ought to have his recompense". ${ }^{37}$

To correct the perceived floodgates risk, the Commission recommended retention of the Alcock requirement for a close tie of love and affection to a primary victim. ${ }^{38}$ While this requirement is advanced in part on a principled basis, as those with close ties are those most

31 Law Commission 1998, above n 1, Executive Summary, iii; para 6.10; para 6.16, rec 11.

32 Law Commission 1998, above n 1, paras 2.63-2.65, 5.33, rec 7. The cases referred to are Sion v Hampstead Health Authority [1994] 5 Med LR 170 (CA); Taylorson v Shieldness Produce [1994] PIQR P329 (CA).

33 Law Commission 1998, above n 1, para 6.8

34 See Law Commission 1998, above n 1, para 5.31. See Ramstead, above n 2, 33 per Thomas J; For the analysis of Denise Bates QC on this point: Denise Bates QC "Liability for Mental injury - Has Pandora's Box Been Opened?" (Unpublished paper, 1999).

35 Law Commission 1998, above n 1, para 6.8.

36 Mullany and Handford, above n 1,311-312; Ramstead, above n 2, paras 94-95, per Thomas J dissenting.

37 Ashby $v$ White (1703) 2 Ld Raym 938; 92 ER 126, 137, quoted by Thomas J, in Ramstead above n 2, para 94.

38 Law Commission 1998, above n 1, para 6.16, rec 11. 
likely, and therefore most foreseeable to suffer injury, ${ }^{39}$ the restriction is clearly recommended to avert the perceived floodgates risk. The Commission considers that rather than take the risk, it should leave the courts to develop the common law. While they may envisage courts allowing some deserving cases absent close ties, this seems unlikely after Alcock and White $v$ Chief Constable of South Yorkshire. ${ }^{40}$

The Commission's recommendations for legislative reform have not been taken up. Indeed, White must be seen as a further tightening of restrictions, to at least preserve negative "fairness" - if traumatised families cannot recover, then nor should rescuers. Some liberalisation may however be apparent. In a unanimous decision, the House of Lords recently refused to strike out negligence claims by parents for nervous shock, when their children were sexually abused by a foster child allegedly negligently placed with them by a welfare agency. ${ }^{41}$ The House allowed the arguments that the parents were either primary victims as participants, or secondary victims sufficiently close in time and space despite no direct perception of the relevant events which occurred over a four week time span, to proceed to trial. The House was undoubtedly influenced by the "deserving" nature of the victims, and apparent grossness of the negligence, but it nevertheless appears that Alcock may not be the last word on proximity or "shock".

\section{B Australia}

Australia originally mirrored the English position, but has recently been somewhat more liberal, albeit not at High Court level. Jaensch $v$ Coffey is the leading case and mirrors McLoughlin. The case confirms the need for foreseeability of psychiatric injury to plaintiffs of

39 See Law Commission 1998, above n 1, para 6.11, quoting Deane J's reference in Jaensch v Coffey, above n 1,600, to expert opinion that: "[T] he most important explanation of nervous shock ... is the existence of a close, constructive and loving relationship... (a 'close relative') and ... it is largely immaterial whether the close relative is at the scene... or how she learns of it".

40 White v Chief Constable of South Yorkshire [1999] 1 All ER 1 (HL). Another Hillsborough case, dealing with police constables who suffered psychiatric injury as a result of their roles as rescuers. The majority of the House of Lords used the absence of any physical danger to the rescuers to distinguish Chadwick v British Transport Commission [1967] 2 All ER 945 (QB), and deny recovery. The decision explicitly relies on the arguably irrelevant consideration that professional rescuers should not be better off than bereaved relatives: per Lord Steyn, 37.

$41 W$ 1-6 (AP) $v$ Essex County Council and Another (16 March 2000) unreported, House of Lords <http:/ / w w w.parliament.the-stationery-office.co.uk/pa /1d199900/1djudg mt/jd000.../w 1-6.ht>. 
normal susceptibility, ${ }^{42}$ and that there must be a "shock" to cause it. ${ }^{43}$ Otherwise Brennan J was prepared to rely on reasonable foreseeability of psychiatric injury and causation to decide cases, ${ }^{44}$ whereas Deane J, in an influential judgment referred to and quoted from at length in Ramstead, looked for additional proximity factors, essentially similar to those in McLoughlin. ${ }^{45}$ However, in preferring a formulation of "causal proximity" over a more narrow or mechanical physical proximity, to exclude cases where the plaintiff has not seen the event or its aftermath, His Honour laid the foundation for later liberalisation. The line of development can be seen in his comment, quoted by Blanchard $\mathrm{J}$ in Ramstead, ${ }^{46}$ that it is difficult to discern a reason why a wife too devastated after being told of a death to attend the death scene cannot recover, when one who attends the aftermath at a hospital of a serious but not fatal injury, can.

The relevant later cases are Spence v Percy, Coates v GIO, Reeve v Brisbane CC, and Pham v Lawson. ${ }^{47}$ The plaintiff in Spence failed to recover, having suffered shock anxiety and stress when she was told of her daughter's accident, saw her in a bad state, and had to nurse her and deal with fits. After her daughter died unexpectedly the plaintiff developed depressive neurosis. There was held to be insufficient causal proximity between the occurrence of mental illness and the original accident. ${ }^{48}$ Spence and similar cases therefore confirm the continuing need for a sudden shock.

Coates, Reeves and Lawson on the other hand take up the invitation from Jaensch $v$ Coffey to dispense with the need for presence at the accident or aftermath. Although the majority in Coates found no psychiatric illness, Kirby P disagreed on the facts, and went on to state that the requirement for direct perception was "hopelessly out of contact with the modern world of communication s". ${ }^{49}$ Significantly he suggested, drawing on modern medical understanding

42 Jaensch $v$ Coffey, above n 1, 587, 567.

43 Jaensch $v$ Coffey, above n 1, 565

44 Jaensch $v$ Coffey, above n 1, 577.

45 Jaensch $v$ Coffey, above n 1, 607.

46 Ramstead, above n 2, para 49.

47 Above $\mathrm{n} 1$

48 See discussion in Ramstead, above n 2, para 50. See also Anderson v Smith (1990) 101 FLR 34, 50, another nursing case after an earlier accident, where illness was found to be the result of "prolonged contact with a complex set of stressful events".

49 Coates $v$ GIO, above n 1,10 . 
that it is as much a plaintiff's emotional involvement in an accident as any physical presence which may lead to injury. ${ }^{50}$ As Blanchard $\mathrm{J}$ notes,${ }^{51}$ Reeves and Lawson adopt a similar approach.

Therefore, despite the protests of some, ${ }^{52}$ Australia appears to be moving towards a position broadly similar to that advocated by the Law Commission. It remains to be seen after Ramstead, whether New Zealand will adopt a similar approach.

\section{New Zealand Prior to 1992}

New Zealand nervous shock law has been slower to develop than overseas. Little relevant case law arose before the Accident Compensation Act 1972 replaced tort liability for personal injury by accident and imposed a bar on plaintiffs suing for injury. ${ }^{53}$ Compensation for pure mental injury therefore first developed as a class of accident compensation under the 1972 and 1982 Acts.

Although a Ministerial review in 1995 felt able to assert that "it is extremely doubtful that the architects of the ACC scheme ever envisaged secondary trauma being included",54 it was in fact almost inevitable that scheme coverage would extend to pure mental injury, including secondary injury to non-participants, once mental injury was included in the definitions added to the Act, shortly after it came into force. ${ }^{55}$ The Ministerial review's assertion is in fact questionable, given the emphasis of the Woodhouse Report on "bodily injury by accident". ${ }^{56}$ It

50 Coates v GIO, above n 1, 11. See also discussion in Ramstead, above n 2, paras 51-56. Kirby $\mathrm{P}$ also cast doubt on the need for a direct shock as a catalyst - illness caused by grief may be enough: Coates v GIO, above $\mathrm{n} 1,12$.

51 Ramstead, above n 2, para 53. See Witting, above n 1, 77-78 for discussion of Reeves and Lawson.

52 See Witting, above $\mathrm{n} 1,73$.

53 See Ramstead, above n 2, para 63, for Blanchard J's easy rejection as irrelevant the old case of Furniss $v$ Fitchett [1958] NZLR 396 (SC).

54 Accident Rehabilitation and Compensation Insurance Corporation Accident Compensation 1995 (Government Print, Wellington, 1995) para 6.13.

55 Accident Compensation Amendment Act 1974, s 2(1). See especially s 2 (a)(i): personal injury by accident includes "the physical and mental consequences of any such injury", and s 2(a)(iv), which implies that "mental or nervous shock" amounts to "actual bodily harm".

56 Report of the Royal Commission of Inquiry Compensation for Personal Injury in New Zealand (Government Printers, Wellington, 1967), para 289(a) [The Woodhouse Report]. 
took some time for the matter to come before the Courts, and it was the subject of conflicting decisions at High Court level in the early 90s. ${ }^{57}$ As Rosemary Tobin has pointed out, ACC itself, apparently influenced by the McLoughlin decision, appears to have been prepared to countenance mental injury claims before changing its approach and contesting such claims. ${ }^{58}$

The matter was settled for primary victims suffering no "physical" injury by the Court of Appeal decision in $A C C v E,{ }^{59}$ and for secondary victims by $A C C v$ Cochrane, a case involving a mother being called to the hospital to watch her viciously beaten son deteriorate and die, over a 20 hour period. ${ }^{60}$ Greig $\mathrm{J}$ regarded the mother's experience as an accident, and was not troubled by nervous shock limitations such as the extent of any aftermath. ${ }^{61}$ This is not surprising given the different basis for accident compensation. Accident compensation was a replacement of a tort, fault-based system, with a novel no-fault approach. Limitations in tort aimed at lessening the impact on unlucky tortfeasors have no place in a no fault system. However in the few remaining cases decided as ACC cases before the 1992 Act excluded them, tort rules do appear to have had an influence. ${ }^{62}$

While in fact the criteria adopted by the ACC Appeal Authority do not exactly mirror McLoughlin, ${ }^{63}$ it is nevertheless clear that at least lower level tribunals had not completely worked through the basis for compensation. It will be argued below that Greig J's approach, asking simply, "was there an accident?" and "did it cause the injury?" is preferable to any

57 Compare $A C C$ v [1991] 1 NZLR 234, 241 (HC), which held that mental injury had to accompany a physical injury to be compensable, and $A C C v E$ [1991] 2 NZLR 228, 232 (HC) which held that mental consequences alone could amount to injury.

58 Rosemary Tobin "Nervous Shock, The Common Law; Accident Compensation?" [1992] NZLJ 282, 285.

$59 A C C \vee E$ [1992] 2 NZLR 426, 434 (CA). The plaintiff, a female senior staff member in a large organisation, was sent on a management course. The course was deliberately challenging and extremely rigorous. After four days she suffered a serious nervous breakdown, suffered ongoing depression symptoms and had to leave her work. The Court concurred with the views of Greig J at first instance, above $\mathrm{n} 57$, and overruled $A C C v F$, above $\mathrm{n} 57$. There was no need for a separately identifiable incident, or for physical injury to found a claim.

60 Cochrane v ACC [1994] NZAR 6, 7 (HC). ACC was refused leave to appeal.

61 Cochrane $v A C C$, above n $60,9$.

62 Thomas $v$ ACC [1994] NZAR 322 (ACAA). See Geoff McLay "Nervous Shock, Tort and Accident Compensation: Tort Regained?" (1999) 30 VUWLR 197, 205.

63 See Thomas $v$ ACC, above n 62, 328-329. While the "member of the immediate family" rule is very similar, there is no real equivalent to the time and space or direct perception limbs in McLoughlin. 
hybrid of tort and ACC. ${ }^{64}$ Even more simply, it should be enough to follow the Court of Appeal and ask "has there been accidental injury"? ${ }^{65}$

\section{The 1992 Act and Beyond}

The confirmation that ACC included pure mental injury was of course short-lived. The court decisions coincided with a change of government and business concern over the costs to employers of ACC. The Government instituted a working party to find ways to make ACC "fairer", mainly to employers, and keep costs down. ${ }^{66}$ The Working Party Report led to a 1991 budget policy document, ${ }^{67}$ and to the 1992 Act. One part of the changes was the exclusion of pure mental injury, except where consequent on certain criminal acts, mainly sexual abuse. ${ }^{68}$ The Government acknowledged that this could mean the return of a right to sue in some pure mental injury cases, ${ }^{69}$ and this was confirmed by Palmer.$^{70}$ That case, involving clear sight of a fatal accident to one's spouse leading to psychiatric illness, met any existing restrictions on recovery, and it was left to the more marginal case of Ramstead to begin to define the limits.

It is highly arguable that the decision to exclude pure mental injury from ACC was made with little thought, based on scanty evidence, using misleading premises, and for the wrong reasons. The overwhelming interest of the working party in finding ways to limit costs and shift them from employers is evident throughout their report. ${ }^{71}$ The report therefore proposes

64 Cochrane $v A C C$, above n 60, 9-10

$65 A C C \vee E$, above $\mathrm{n} 59,431$. Such a test will of course depend on the requirements of legislation, as to whether an identifiable "event" is nevertheless required as is the case with the 1992 Act.

66 Department of Labour Report of the Ministerial Working Party on Accident Compensation (Wellington, 1991) 1 [Working Party Report]. The Working Party does not appear to have been driven by any actual increase in employment-related stress claims - E's case is genuinely novel in the reported cases. Leitch $v$ $A C C$ (1990) 8 NZAR 26 (ACAA), dealt with a stressed prison nurse, who failed to recover. Cogan $v$ ACC (1990) 8 NZAR 145 (ACAA), which allowed at least the possibility of recovery for a secondary victim, was a medical misadventure case involving the parent of a child who suffered misadventure.

67 Minister of Labour Accident Compensation - A Fairer Scheme (Wellington, 1991).

68 Accident Compensation and Rehabilitation Act 1992, s 8(3).

See $A$ Fairer Scheme, above n 67, 17.

70 Queenstown Lakes District Council v Palmer, above n 7.

71 See for example Working Party Report, above n 66, 3 "Problems with the Existing Scheme". The working party was prepared to see significant restrictions placed on the scheme, despite terms of reference which included maintenance of "acceptable" levels of income support, see Executive Summary, 1. 
several major changes to ACC, such as replacement of lump sum payments for disability with allowances and abolition of payment for pain and suffering, restriction of employer contribution to work injury, and experience rating of employers' claims histories. ${ }^{72}$ In addition, the report made numerous detailed recommendations, aimed at "clarifying" or more correctly limiting the extent of possible coverage. ${ }^{73}$ Stress and mental injury was dealt with in this section, with little argument. ${ }^{74}$

What argument there is shows the paramountcy of unquantified cost fears. Cover for stress is identified as a major driver of the increasing cost of workers compensation overseas. Stress should not be covered because the workplace is not the only source of stress, and employers should only have to pay for injury where they can influence the "accident inducing behaviour". Recent court decisions were taken as signs the boundary between stress and personal injury was being breached. Therefore stress should be excluded, along with mental injury, to prevent stress claims entering "through the back door". 75

The flaws in these arguments are obvious. The implication that workplace stress is not an "accident inducing behaviour" which employers can influence is extraordinary. The possibility of a mixture of different stressors is a question of fact relevant to causation, whether for an ACC claim, or in tort. In any case, it is surely an overreaction to remove all mental injury, merely to prevent one possible cause of mental injury - stress - from affecting one class of accident claims (work accidents). The easy equation of stress with mental injury shows that the working party is guilty of the error which they have falsely accused the courts of. The plain tiff in $E$ 's Case succeeded not because of stress, but because mental injury was proven. ${ }^{76}$ While Cochrane and Thomas can be taken as suggesting that recognised psychiatric illness is not required - the point finally resolved in Ramstead by making such illness essential to recovery -

72 Working Party Report, above n 66, recommendations 13, 16, 20, 25.

73 See for example Working Party Report, above n 66, 11 recommendations relating to the Annex to Chapter 4. The recommendation on stress and mental injury is included as recommendation 51.

74 Working Party Report, above n 66, 88. Stress and mental injury are dealt with in the annex, in four brief paragraphs.

75 Working Party Report, above n 66, 8, paras 361-364.

$76 A C C \vee E$, above $\mathrm{n} 52,434$ : "This case is not involved with mere humiliation or distress but with serious mental disorder". Compare Cochrane v ACC, above n 53, where Greig J found an unresolved prolonged grief reaction to be mental injury, albeit despite no medical evidence of "psychiatric disorder". 
it is nevertheless clear that something approaching it would be required ${ }^{77}$ In any case these cases were decided well after the working party reported. Its disquiet would appear to be unreasonably based on the judgment of the High Court in E's Case. ${ }^{78}$

In noting the experience of other countries, the working party does not identify which. It is easy to speculate that the working party may have been unduly influenced by the United States experience. Nicholas Mullany has pointed out that in fact United States courts typically do not differentiate between "emotional distress" and recognisable psychiatric illness: in many jurisdictions recovery can be had for either. ${ }^{79}$ We should be suspicious of any argument that mental injury would open floodgates for ACC. E's Case and Ramstead itself are clear indicators that the courts can and will police the backdoor.

It therefore appears that mental injury was returned to the tort field by an expedient desire to reduce employer ACC costs. The decision was admitted to be arbitrary, ${ }^{80}$ and did not deal with changing understandings of mental illness or the difficulty of distinguishing between physical and mental injury. ${ }^{81}$

\section{THE DECISION IN RAMSTEAD}

\section{A Background}

The recent Court of Appeal decision represents the end of a long series of criminal and civil actions arising from alleged negligent treatment at Christchurch Hospital in 1992. Several patients died unexpectedly during thoracic surgery and the surgeon was prosecuted and convicted for manslaughter, before successfully appealing to the Privy Council. ${ }^{82}$ Four relatives of deceased patients and one survivor then sued for negligence, alleging "mental distress" to both patients and next of kin. The next of kin sued as both personal representatives

77 See Thomas $v$ ACC, above n 62, 328.

79 Mullany, above n 8, 144.

80 Working Party Report, above n 66, 88 para 364.

81 See $A C C v E$, above n 59, 434; Coates $v$ GIO, above n 1, 12 per Kirby P; see also Page v Smith, above n 1 , 188 per Lord Lloyd.

$82 \quad R v$ Ramstead [1999] 1 NZLR 513 (PC). 
of the deceased, and on their own behalf, for the mental suffering on learning what happened to their loved ones. ${ }^{83}$

The relevant events straddled the coming into force of the 1992 Act. Two plaintiffs were subject to the 1982 Act, three to the 1992 Act. No doubt to avoid those subject to it being caught by the bar in the 1982 Act, all plaintiffs disclaimed psychiatric injury. With hindsight, the one husband seeking redress for his suffering after July 1992 would have been well advised to investigate whether his distress did amount to psychiatric injury.

The claims were all struck out by Master Venning, except for a claim for exemplary damages by the survivor. The personal representative claims were barred by either the 1982 or 1992 Act, the 1982 Act next of kin cases were also barred as mental consequences of an accident, and in any case the next of kin cases, could not succeed as they disclaimed any recognisable psychiatric illness. ${ }^{84}$

\section{B Preliminary Matters}

The Court of Appeal readily disposed of all but the three claims by next of kin for their personal suffering. The Master was correct, and all the personal representative and the one personal claim for compensatory damages were barred as arising directly or indirectly from medical misadventure. ${ }^{85}$ The plaintiffs had one temporary victory however, in that the Court was prepared to proceed on the basis that the first two plaintiffs' claims were not barred by the 1982 Act, as there was no psychiatric injury, and therefore no personal injury by accident. ${ }^{86}$

The judgments then concentrated on the rules to be applied in what the Court happily denoted as "secondary victim claims". While the majority alluded to the difficulty of making the primary/secondary distinction, the matter was not controversial on the facts, and a straight-forward albeit incomplete definition was propounded. ${ }^{87}$

87 Ramstead, above n 2, para 21: " A secondary victim is a person who experienced mental suffering but was not physically injured or placed in physical danger by the defendant's negligence". This would appear to exclude unendangered rescuers from recovery. The parents in W1-6 (AP) v Essex County Council and Another, above n 41, would also be restricted to a secondary claim, despite their claim to be "participants". 


\section{The Majority Judgment: Joining Australia?}

The majority first reviewed the overseas authorities, paying particular attention to the United Kingdom and Australian cases. Interestingly, Blanchard J considered the English authorities pointed to a three part test involving: ${ }^{88}$

(1) the nature of the secondary victim's mental suffering;

(2) The physical proximity of the secondary victim to the primary victim's accident or misadventure; and

(3) The relational proximity (the closeness of the relationship) of the primary and secondary victims.

His Honour considered this was demonstrated by reference to McLoughlin and Alcock and discussed the cases extensively. However as that discussion shows, the nature of the suffering (recognisable psychiatric injury) is in reality a necessary precondition to the three part test, which includes as its third element direct perception of the accident causing injury. ${ }^{89}$ This is an initial indication that the majority sees the psychiatric injury requirement as crucial, while being rather less wedded to other proximity limitations. This suggests the Court is inclined to the Australian approach, as sufficient to limit fraud and floodgates concerns.

Blanchard $J$ then proceeded to decide the case for the defendants, on the need for recognisable psychiatric illness. The requirement appears to be treated as necessary on policy grounds, rather than correct in principle. A clear line needs to be drawn, at a sufficiently high level, to avoid floodgates concerns. ${ }^{90}$ The Court is clear that "grief per se" is not compensable, and does note the point made by the Law Commission of psychiatry's distinction between mental distress and psychiatric disorder or illness. ${ }^{91}$ In the end however, it is the danger of opening the door too wide, or too vaguely, which convinces that this should be the standard. ${ }^{92}$

88 Ramstead, above n 2, para 26.

89 Ramstead, above n 2, para 38: see Blanchard J's citing of Lord Hoffman's summary of the test from White above n 1, 41; see also para 43, quotation from Law Commission 1998.

90 Ramstead, above n 2, para 68.

91 Ramstead, above n 2, para 65.

92 Ramstead, above n 2, para 69. 
Despite the arguments from Thomas $\mathrm{J}$ that this restriction is indeed only an arbitrary mean $\mathrm{s}$ of limiting claims, ${ }^{93}$ the majority could have suggested a principled basis for it. The Law Commission comment suggests a principled distinction, even if only of degree and not always easily identified. It makes sense in an admitted grey area to allow recovery only where there is clearly "injury". The distinction is therefore not arbitrary like the time, space, and direct perception limitations, that is without any logical relationship to the thing being limited. The courts would then be applying a reasoned distinction between everyday albeit distressing states such as grief, and something which is analogous to and logically indistinguishable from physical harm. The use of "recognisable" allows the courts to deal with developments or cases where medical classifications do not assist. This a point which with respect Blanchard J seems to overlook: "pathological grief" which he refers to is a legally accepted category, but not within the current standard medical classifications, where his Honour appears to assume it fits. ${ }^{94}$ A more principled approach to recognising psychiatric illness could also address Thomas J's concerns about arbitrariness and deserving cases: some may be recognisable as psychiatric illnesses even if they do not fit currently accepted medical classifications.

The remainder of the judgment provides brief guidance on some but not all of the remaining requirements for recovery. It decides, obiter, that there must be some close and loving relationship to satisfy relational proximity. ${ }^{95}$ There is no indication whether this is seen as a natural outworking of reasonable foreseeability - those with loving ties being the most, possibly only ones likely to suffer injury - or is, as for the Law Commission, also necessary to remove the possibility of a flood of claims from a single event. ${ }^{96}$ Given the reasoning on psychiatric illness it is highly likely that floodgates concerns were at work here as well. For whichever reason, the majority essentially adopts a categorical approach, albeit what it hopes will be a "sufficiently flexible" one.

No comment is made on a "normal phlegm" requirement. It is impossible to tell whether it is intended that this be dealt with as part of reasonable foreseeability as recommended by the

93 Ramstead, above n 2, para 100.

94 Ramstead, above $\mathrm{n}$ 2, para 66. See Mullany, above n 8, 103 n 5 on pathological grief. Despite assumptions in the judgments to the contrary, Mullany himself appears to agree that psychiatric injury is a reasoned approach, not an arbitrary policy limitation, so long as it is not confined merely to conditions described in DSM-IV or ICD-10.

95 Ramstead, above n 2, para 72.

96 Law Commission 1998, above n 1, para 6.8. 
Law Commission, ${ }^{97}$ or whether in fact the limitations imposed by Page $v$ Smith ${ }^{98}$ apply in New Zealand. It is suggested with respect that the Law Commission approach will be preferable, if and when this matter is in issue in New Zealand; this fits better with the cautiously liberalising approach of the majority, and removes another potentially arbitrary and unnecessary limitation to recovery. Victims will still be unable to recover of course if no injury, psychiatric or otherwise, is foreseeable.

On the physical proximity requirement the majority leans towards Australia, particularly Kirby P's dissenting approach in Coates $v$ GIO. ${ }^{99}$ The Court does not have to decide the issue and does not, but appears swayed by the force of Kirby P's argument, to the point that it may be prepared to remove or relax the Alcock restrictions should a case arise. ${ }^{100}$ The fact that the judgment does not discuss a direct perception requirement also argues against any perceived need for time and space proximity. The majority may well be satisfied that the floodgates are sufficiently held back by relational proximity, recognisable psychiatric illness and perhaps "normal phlegm", and they can therefore afford to listen to criticisms of the irrationality of the "time and space" requirement.

The judgment carefully states that it is expressing no view on the necessity of a "shocking incident involving actual or threatened injury to a primary victim". ${ }^{101}$ In reality the decision not to comment suggests the requirement is gone, or radically changed. The judgment implies unseen negligent surgery may be enough - knowledge of, rather than experience of some shocking circumstance may be enough. This is a logical corollary of deleting physical proximity and direct perception requirements, and shows the majority favours the Australian view that being told of a shocking event is enough.

Overall the majority has taken a cautious approach, carefully limiting the potential for too much liability even as the categories are extended. Once again, floodgates arguments have held sway, even as the Court has been prepared to crack open the gates a little.

97 As the Law Commission suggests: Law Commission 1998, above n 1, para 5.27.

98 See above Part II A.

99 Coates $v$ GIO, above n 1, 10-12.

100 Ramstead, above n 2, para 74.

101 Ramstead, above n 2, 28, para 73. 


\section{Thomas J's Judgment: Reasonable Foreseeability Unchained}

If Alcock and White $v$ Chief Constable represent the most restrictive approach, and the majority in Ramstead a more moderate version of that, then Thom as $\mathrm{J}$ champions the principled approach. Cases can be determined on reasonable foreseeability alone, with no need or justification for resort to policy restrictions, especially arbitrary ones. ${ }^{102}$

This approach has a considerable pedigree, which Thomas J acknowledges. ${ }^{103}$ In particular, Thomas J echoes Lords Bridge and Scarman in McLoughlin, and draws heavily on Nicholas Mullany. The thesis is that additional proximity restrictions cut across the "fundamental principle that damages are recoverable in negligence where the defendant owes the plaintiff a duty of care and the harm which ensues is reasonably foreseeable". ${ }^{104}$ The law should only impose additional restrictions where there are clear and logical policy reasons for doing so, which can be defined without being arbitrary. ${ }^{105}$

Thomas J correctly identifies that floodgates concerns are the main policy objection to be dealt with, and agrees with Lord Bridge that they have been "greatly exaggerated". ${ }^{106}$ His arguments have considerable force: previous relaxations on recovery for nervous shock or mental injury have not led to floods, reasonable foreseeability itself imposes a safeguard against unrestricted liability, and even if there is an increase in justifiable claims this is no reason to deny a remedy for a wrong, merely because litigation increases. ${ }^{107}$

Perhaps the one objection his Honour does not deal with adequately is the potential for a single event to lead to a flood of actions, and for this to lead to liability arguably disproportionate to the original negligence. The problem is noted as the reason behind the Law Commission's allowing restrictions beyond reasonable foreseeability, ${ }^{108}$ but is not really rebutted. The concern is significant, and lends credence to views such as those of Witting, that

102 Ramstead, above n 2, para 83.

103 Ramstead, above n 2, para 79, para 86.

104 Ramstead, above n 2, para 108

105 Ramstead, above n 2, para 85.

106 Ramstead, above n 2, paras 89-91.

107 Ramstead, above n 2, paras 92-95.

108 Ramstead, above n 2, para 88. 
Alcock-type proximity restrictions are needed to avoid injustice to unlucky tortfeasors. ${ }^{109}$ It may be that the answer is to be found in the reasonable foreseeability safeguard, or simply in the resilience of the human mind: in determinate numbers of claims from a single event will not succeed, as given the human mind's natural resistance to trauma, few will be sufficiently affected by even horrific events, and even if they are, due to peculiar susceptibility, then lack of foreseeability may step in. ${ }^{110}$ It seems likely however that the concern with potentially disproportionate consequences will continue to influence courts to exercise caution, meaning arbitrary restrictions will continue to find favour, for purely pragmatic reasons.

Thomas $\mathrm{J}$ sees restriction to recognisable psychiatric illness as another arbitrary and unwarranted limitation. This is unfortunate, as it tends to detract from the force of the argument. If, as suggested above, this requirement as properly and broadly understood is correct in principle, then Thomas J's reasoning could support a duty where there is reasonable foreseeability of recognisable psychiatric illness. Considerations of the nature of any shock, closeness in time and space, and the relationship of victims would be relevant to questions of foreseeability and causation, ${ }^{111}$ but need not become arbitrary limits. Circumstances such as unforeseeably susceptible plaintiffs would also be allowed for. Such would appear to be a "reasonable" alternative to the cautious categorical approach of the majority, whereby justice, at least by tort standards could be done, without the prospect of a flood of claims. Whether this is the best or most practical approach to compensation for psychiatric injury in New Zealand, is discussed below.

\section{AFTER RAMSTEAD: WHERE NOW?}

New Zealand appears to have a law of nervous shock which is, at least, not as arbitrary as the United Kingdom's, but which is still very much driven by floodgates concerns. Thomas J has suggested simple reasonable foreseeability as the better approach, and it may be that a

109 See Witting, above n 1, 66, and 87-94. Witting argues that notions of corrective justice demand limits on liability. It is however arguable that at Hillsborough itself, any liability to even large numbers of psychiatrically ill secondary victims, if they existed, would not have been out of proportion to the gross negligence involved.

110 See Nicholas Mullany and Paul Handford, above n 1, 312-313, and Witting, above n 1, 69 n 49 on the relative unlikelihood of psychiatric injury. See also discussion in $\mathrm{n} 113$ below.

111 Mullany and Handford, above n 1, 312. Thomas J refers to this passage, Ramstead above n 2, para 86, taking the relevance to be to causation. The authors appear to be referring to foreseeability. Such factors can of course be relevant to either inquiry, but need not in themselves be determinative. 
combination, of reasonable foreseeability of recognisable psychiatric illness, would be a still more defensible solution. However, none of these approaches adequately addresses two basic questions: should society allow compensation for mental injury in the first place? Even if it should, is tort law the best way to do it?

\section{A The Case Against Compensation}

At first sight compensation is a practical reality. Some compensation has been available for a hundred years, and the courts start from a presumption that compensation should be available to deserving cases - the only disputes being over the standard to be applied. ${ }^{112}$

A plausible case can in fact be made for no compensation for mental injury, especially in tort. If reasonable foreseeability is required, then it can be argued that recognisable psychiatric illness is in fact very rare, is largely dictated by the susceptibilities of the individual and is therefore not reasonably foreseeable. ${ }^{113}$ Even for more common psychiatric illnesses, such as depression, there are both foreseeability issues and causation difficulties with linking the illness to compensable events. Should a potential tortfeasor be in danger of liability for a plaintiff's allegedly reactive depression, when perhaps twenty per cent of the population may suffer from depression in their lifetime, for whatever cause, including issues of self esteem? The argument suggests that an "eggshell personality" approach can only go so far (if justified at all) and should not extend beyond say primary victims who are placed in some real danger. Also, evidence suggests suing is unproductive or counterproductive to mental illness sufferers. ${ }^{114}$ There is no justification for allowing court action when the plaintiff may be hindered by it.

At more of a policy level, Jane Stapleton has argued that the bewildering mess of nervous shock law is so confused and unedifying it brings the law into disrepute and should be deleted altogether. ${ }^{115}$ The argument here is that it would be better to deny liability to all potential victims, rather than have relatives protesting their love in court, or "com peting" with the claims

112 The courts in Bourhill, McLoughlin and Alcock, all above n 1, agree on availability in so me cases.

113 See Mullany and Handford, above n 1, 312-313, and Witting, above n 1, 69 on the relative unlikelihood of psychiatric injury, especially the most "likely" injury, post traumatic stress disorder for which a range of susceptibility factors are critical, none of which will be affected by a direct tortfeasor.

114 Law Commission 1998, above n 1, 53 n 91.

115 Jane Stapleton "In Restraint of Tort" in Peter Birks (ed) Frontiers of Liability (Oxford University Press, Oxford, 1994) 95. 
of rescuers. This is surely a radical approach, but hardly addresses the question of what harms deserve remedies.

It can of course be argued that problems of foreseeability, causation and the effect of proceedings are not unique to psychiatric injury - classes of physical injury, such as back injury, can be similarly criticised. Also, many other "unedifying spectacles" can be found in tort law, for instance family members suing each other for physical harm after a road accident, before ACC. These are therefore criticisms of the tort system, or recognition of its limitations, rather than reasons to deny compensation altogether.

The 1995 Government review of ACC argued that compensation for secondary victims was never intended to be part of the scheme, and such injuries could be considered part of the vicissitudes of everyday life. The review team also thought there would be difficulty distinguishing between witnesses to a gang beating and the survivors of an earthquake. ${ }^{116}$ The latter argument is obviously a perceived need for a policy distinction, as it is difficult to see in principle why the former is any less "shocking" than the latter - the distinction is merely one between secondary and primary victims. The first argument by contrast adheres to older, largely discredited views of mental disturbance, as somehow different from and somehow not so "real" as physical harm.

The courts are, however, increasingly swayed by the growing impossibility of distinguishing mental injury from physical. This is a key point for Kirby $\mathrm{P}$ in Coates, ${ }^{117}$ and can be seen in both Alcock and Page $v$ Smith. ${ }^{118}$ On this basis, any decision to allow recovery for physical harms, but not psychiatric ones becomes hard to defend, unless the need for arbitrary limits is accepted. Once it is accepted that mental injury is as much a wrong as physical harm, even if a more slippery one, then the law is logically obliged to find some way of providing relief. Arguably a prohibition on recovery for psychiatric injury would today be socially and

116 Accident Compensation 1995, above n 54, para 6.13.

117 Coates $v$ GIO, above n 1,12 .

118 Alcock, above n 1, 406-407 per Lord Oliver; Page v Smith, above n 1, 188 per Lord Lloyd. See also McLoughlin v O'Brien, above n 1, 433 per Lord Bridge, referred to by Lord Lloyd. 
politically unacceptable. ${ }^{119}$ This then leads courts down the paths of McLoughlin, Alcock and Ramstead, to try to find a defensible balance.

\section{B Can Tort Law Cope?}

Witting argues an appropriate balance can be struck by accepting Alcock-type limitations as necessary to satisfy "event" and causal proximity requirements. ${ }^{120} \mathrm{He}$ argues those such as Mullany who argue for the loosening or abandoning of restrictions are focussing too much on the victim, and not enough on the actual extent of the wrongful action of the tortfeasor. Event and causal proximity requirements are therefore justified by corrective justice theories, as they avoid disproportionate liability. ${ }^{121}$

The problem with Witting's analysis is the difficulty in establishing that such limits will do what he says. They act to limit liability, but whether they do so fairly or proportionately is a purely arbitrary result. Notions of corrective justice cannot justify a need for event proximity in every case.

If Witting's approach is unsatisfactory, Thomas J's or Mullany's alternative is unlikely to win wide acceptance. While there are good arguments for it, courts and policy-makers will continue to worry about the potential for disproportionate liability. It is possible also to question, as George Christie has done, whether just too much is being asked of a good but limited principle - arguably we should be more pessimistic than Thomas J about the capacity for reasonable foreseeability to decide all cases. ${ }^{122}$

\section{An Accident Compensation Alternative}

If none of the tort formulations appears ideal, it is sensible to ask whether ACC can step back in. This is especially so, given its original removal was both poorly conceived, and done

119 Accident Compensation 1995, above n 54, implicitly accepted this, in acknowledging that secondary victims would seek compensation in tort, if it were not available in ACC, and that for this reason alone, perhaps it should be re-incorporated.

120 Witting, above n 1, 71-79.

121 Witting, above n $1,66,90-94$.

122 See George C Christie "The Uneasy Place of Principle in Tort Law" in David Owen (ed) Philosophical Foundations of Tort Law (Clarendon Press, Oxford, 1997) 113, 120-121. While the analysis concentrates on the limits on reasonable foreseeability in economic loss cases, Christie points to McLoughlin as another case where the debate arises. The sharply divided judicial opinions in most of the leading cases suggest the potential limits on reasonable foreseeability. 
before ACC compensation had been tested in practice. ${ }^{123}$ ACC cover logically extends to accidental psychiatric injury occurring without accompanying "physical" injury. ${ }^{124}$ Arguably therefore, psychiatric injury should be placed back with other forms of compensable injury, unless there are compelling policy reasons for continuing what must be an arbitrary separation. In actual fact, return to ACC provision is justified, not only by logic or principle, but also because it may deliver superior policy results as well.

The first point to note is that accident compensation does not suffer from several of the difficulties faced in tort. This is hardly surprising, given ACC was designed to replace a tort system perceived to have failed. Therefore, as with other forms of injury, patient rehabilitation is not hindered by litigation, and "unedifying spectacles" are avoided. ${ }^{125}$

More fundamentally, concern over whether reasonable foreseeability can do the job disappears: the tort principle is replaced by the no-fault principle. As reasonable foreseeability is employed to discover whether alleged wrong-doers owe duties of care and are therefore liable, it is simply irrelevant in ACC. The major justification for floodgates concerns given by the Law Commission ${ }^{126}$ of disproportionate liability for a single event, together with Witting's corrective justice concerns are eradicated. The question becomes simply: is this an injury which society ought to compensate?

Such a question can be answered by reference to the guiding principles for the original ACC scheme. ${ }^{127}$ In particular, the principles of community responsibility and comprehensive entitlement, particularly the idea that the injured should receive compensation from any community funded scheme on the same basis regardless of the cause of their injury. ${ }^{128}$ It is true that the original principles talked of compensation for "physical incapacity", ${ }^{129}$ but surely even

123 See above Part II D.

124 This was the basis for the decision in $A C C v E$, above n 59, 434.

125 It is however arguable that a cautious or adversarial approach to ACC case management may be almost as stressful and damaging to victims. This however is more an administrative concern than a structural one. An ACC administrator determining "fair" compensation based on clear criteria should have markedly lower transaction costs than a system based on litigation.

126 Law Commission 1998, above n 1, para 6.6 n9.

127 Woodhouse Report, above n 56 paras 55-62.

128 Woodhouse Report, above n 56, para 55.

129 Woodhouse Report, above n 56, para 55. 
this phrase is broad enough to include psychiatric illness, given the developing medical and social understanding of such illness.

It can be argued that floodgates concerns remain regarding simple proliferation of claims, based on the capacity of the principles to be interpreted broadly, and indeed that it was these that led to the 1992 removal in the first place. Whether ACC is or was generally too broadly or narrowly defined is a bigger subject than that of this article. ${ }^{130}$ However it is submitted that concern over a proliferation of claims should not be given great weight. In the first place, $A C C$ $v E$ suggested, and Ramstead has confirmed, that there must be a recognisable psychiatric illness, for there to be a compensable injury. ${ }^{131}$ Arguably mental injury caused by accidental trauma is just as self-limiting as physical injury - the flood of claims from single or multiple events is simply unlikely to eventuate. ${ }^{132}$

It is also submitted more generally, that the judgments in $A C C v E$, together with Cochrane, provide a satisfactory foundation of Common Law upon which to build, allowing difficult mental injury claims to be fairly assessed, now that the requirement for recognisable psychiatric illness has been established. Claimants will need to demonstrate causation, and in particular, that the illness is the result of an accident, or perhaps, if revised definitions in a new Act so allow, is "accidental injury". 133

It remains open for law drafters to specify any limits to qualifying events, for instance that for secondary victims who have not directly perceived the trauma-inducing event, the event must be one which would nevertheless attract cover for a primary victim, for instance as medical misadventure (the Ramstead situation). Equally, a basic de minimis requirement is justified: accident compensation should not be available unless accidental injury is a substantial operating cause of harm suffered.

130 The subject includes the issue of cover for incapacity due to sickness, which has been contentious since the Woodhouse Report. Note for example the views expressed in Craig Brown and John Smillie, "The Future of Accident Compensation" [1991] NZLJ 249, and the dissenting editorial comment from P J Downie [1991] NZLJ 249.

$131 A C C v E$, above n 59, 434; Ramstead, above n 2, 25, para 65.

132 See above $\mathrm{n} 113$, on the relative unlikelihood and low incidence of mental illness.

133 No doubt it was the perceived broadening of what might be "accidental", both in $A C C v E$, above n 59 and in ACC v Mitchell [1992] 2 NZLR 436 (CA), that led to the tightening of definitions in the 1992 Act. A revised Act allowing mental injury will either need to amend the definition of "accident", or allow for mental injury within a coverage section. 
It should not however be necessary to impose arbitrary Alcock-type restrictions. An accident compensation scheme should logically cover mere bystanders who are genuinely injured by the perception of an accident, and persons, usually family members, who are similarly injured by news of an "accident" to someone else. Even in tort, such victims are denied for reasons of policy, not principle, and it is here that the law is most arbitrary. However, the reason such claims are denied in tort, that is concern over disproportionate liability, is simply absent in ACC. No doubt both bystander and "bad news" claims will be relatively rare, limited by both the psychiatric injury and causation requirements, but they should logically be included in any genuine accident compensation scheme claiming universality, as injuries which can and do arise "acciden tally". ${ }^{134}$

ACC is also likely to do a better job for mental injury victims than the tort system, and at a reasonable cost. The compensation available under accident compensation is certain to be better targeted and more appropriate to such victims than damages in tort. Compensation is likely to be limited to earnings related compensation for those in employment who are so severely injured as to be unable to work, plus rehabilitation assistance such as counselling. ${ }^{135} \mathrm{It}$ is reasonable to expect that both rehabilitation and income replacement will be temporary for most victims. Accident compensation, and with a genuine focus on rehabilitation, would be particularly well-suited to assisting the traumatised back into their previous lives, in a way that damages awards cannot. The magnitude of the rehabilitation task will no doubt also normally be less than for those suffering major and irreversible physical damage.

These considerations, together with the lack of any real argument put forward in 1991 to quantify the cost of mental injury and justify its exclusion, should logically be enough to satisfy policy-makers that the costs of a return to ACC will be manageable. On a more cynical level, it is almost certainly in the interests of the government, as a major employer of workers in stressful occupations, chronically subject to restructuring and resource pressure, to return to a

134 Any scheme must be universal in nature if it is to justify the continued bar on the right to sue; see Accident Compensation 1995, above n 54, para 3.1. Fair protection of those suffering accidental mental injury is necessary to justify the re-removal of the right to sue in such cases.

135 Government has confirmed a return lump sum payments for permanent disability: see "Lump sum compo plan unveiled" The Dominion, Wellington, 1 December 2000, 1. The scheme will not cover pure mental injury other than the existing sexual abuse categories. Even if payments were to be available to those suffering mental injury, it is suggested they would be likely to be made only after significant treatment and assessment, and would seem unlikely to approach levels for total disability in all but the most extreme cases of accidental mental injury. 
no-fault system. ${ }^{136}$ There is therefore both an excellent principled and pragmatic case for such a return.

The attitu de of private sector employers is much less certain however. The recent business sector antipathy to the return of workplace cover to state provision ${ }^{137}$ strongly suggests that employers will resist any other perceived increase to the domain of State-provided ACC. Private sector employers may well back their ability to avoid significant liability costs in tort, given the barrier imposed by litigation in the first place. The insurance industry is equally likely to wish to avoid any further shrinking of its potential market. Any proposed return is therefore likely to meet with significant and well-organised opposition.

Any government seeking to return mental injury to ACC cover will therefore need to be somewhat resolute, especially if critics are able to suggest the State is merely seeking to pass its own potential liabilities onto society, and particularly employers, as a whole. The current Government has in fact rejected a return to ACC for mental injury, apparently for the old reasons of potential cost, difficulties with definition, and fear of fraud - floodgates, once again. ${ }^{138}$ Despite the Brickell and Gilbert cases, the Minister Responsible for ACC has indicated he would not consider a return to ACC without employer consensus, ${ }^{139}$ and has recently confirmed that a return to lump sum payments will not include witnessing of traumatic events or workplace stress. ${ }^{140}$ Despite a Government claim to be returning to the original principles

136 Gilbert v Attorney General, above n 9, together with Walker v Northumberland County Council [1995] 1 All ER 737 (QB), (see discussion by Mullany, above n 8, 107) should be enough to convince governments of their own interest.

137 See for example editorial comment and summary of opposition The Christchurch Press, Christchurch, 1 July $2000<$ http://www.stuff.co.nz/inl/index/0,1008,215195a1937,FF.html>; "Employers plan ads opposing ACC changes" The Evening Post, Wellington, 9 March 2000, 2; see also "Floodgates", below n 139, re attitude of Employers' Federation.

138 "Labour backed off costly election promises on ACC" The Evening Post, Wellington, 18 January 2001, 9, quoting Department advice to Ministers in March 2000. The advice appears to mirror some of the old attitudes to mental illness, criticised above.

139 Dr Michael Cullen, Minister Responsible for Accident Compensation, reported in "Floodgates may open on claims" The Evening Post, Wellington, 24 June 2000, 3. The same article quotes Employers' Federation opposition to a return to ACC as it could "provoke a rash of claims in an era when "stress is a fact of life"". Employers therefore appear to be adopting the same elision of "stress" and psychiatric injury/illness, which led to the hasty 1992 changes. 
of $\mathrm{ACC},{ }^{141}$ it appears the sensible and justified ACC solution must wait, perhaps until private sector employers have lost some expensive negligence actions.

\section{CONCLUSION}

Accident compensation is a trade-off, of access to compensation, in return for loss of legal rights. There appears to be no sufficient reason why that trade-off should not work as well or better with mental injury, than it does with broken legs. Ramstead shows courts will limit claims to those involving recognisable psychiatric injury, and floodgates concerns are even less of a concern under ACC, than they are - if they are - in tort. Added to this is the far more appropriate nature of the compensation offered by ACC, and its potential to be delivered with out resort to an adversarial contest. It would seem that the time is right to recover from the wrong turning taken in 1992. It is unfortunate the current ACC reform will not now see this mater taken up, despite its obvious merits.

140 Dr Michael Cullen, Minister Responsible for Accident Compensation, reported in "Lump-sum compo plan unveiled" The Dominion, Wellington, 1 December 2000, 1. The same lumping together of stress and mental injury appears to continue.

141 Dr Michael Cullen, above n 140. 